\title{
Faktor Risiko Kejadian Stunting Pada Balita di Kabupaten Kerinci Provinsi Jambi
}

\author{
Eti Kurniawati ${ }^{1}$ \\ STIKES Harapan Ibu, Jambi, Indonesia \\ Email korespondensi : kurniawatieti620@gmail.com
}

\begin{abstract}
ABSTRAK
Pembangunan kesehatan dalam periode tahun 2015-2019 difokuskan pada empat program prioritas, yaitu salah satunya penurunan prevalensi balita pendek (Stunting). Data dari Dinas Kesehatan Provinsi Jambi menurut Kabupaten adalah tertinggi di Kabupaten Kerinci sebesar 35,0\%. Penelitian ini untuk mengetahui faktor risiko kejadian Stunting pada Balita di wilayah Kecamatan Siulak Kabupaten Kerinci tahun 2019. Penelitian ini merupakan penelitian kuantitatif dengan desain Case Control. Pengambilan sampel dengan menggunakan tekhnik Multistage Random Sampling. Sampel dalam penelitian ini adalah ibu yang memiliki balita yang Stunting dan tidak Stunting dengan jumlah sampel 88 responden, sebanyak 44 (kasus) dan 44 orang (kontrol). Instrumen penelitian ini menggunakan kuesioner. Hasil penelitian dilakukan uji chi-square didapatkan Pengetahuan Ibu $(\mathrm{p}=0,032)$, Penggunaan Jamban $(p=0,005)$, Pendapatan Keluarga $(p=0,007)$, ASI eksklusif $(p=0,001)$, MP-ASI $(\mathrm{p}=0,011)$, Imunisasi dasar $(\mathrm{p}=0,029)$, dan Pengasuh Anak $(\mathrm{p}=0,018)$. Hal ini menyatakan bahwa terdapat hubungan antara Pengetahuan Ibu, Penggunaan Jamban, Pendapatan Keluarga, ASI eksklusif, MP-ASI, Imunisasi dasar, dan Pengasuh Anak. Kesimpulan masih perlu upaya yang keras untuk meningkatkan pengetahuan serta merubah perilaku agar masyarakat terdorong melakukan upaya yang baik menjaga kesehatan balita khususnya Stunting. Oleh karena itu, diharapkan Instansi terkait dan tenaga kesehatan untuk lebih meningkatkan perannya dalam memberikan informasi dan upaya terkait faktor-faktor terhadap kejadian Stunting.
\end{abstract}

Kata kunci: Stunting, Pengetahuan, Jamban, Pendapatan Keluarga, ASI Eksklusif, MP-ASI, Imunisasi Dasar, Pengasuh Anak.

\section{Risk factor for stunting in toddlers in Kerinci Jambi Province}

\begin{abstract}
Health development in the 2015-2019 period focused on four priority programs, one of which was the reduction in the prevalence of short children (Stunting). Based on data from the JambiProvincialHealthOffice by district was highest in Kerinci district at 35.0\%. This study was conducted to determine the risk factors for Stunting in children under five in the district of Siulak in Kerinci Regency in 2019. This study was a quantitative study using a CaseControl design. Sampling using MultistageRandomSampling technique. The sample in this study were mothers who had Stunting and not Stunting toddlers with a total sample of 88 respondents, totaling 44 (cases) and 44 people (control). This research instrument uses a questionnaire. Chi-square test results obtained from the Mother's knowledge $(p=0.032)$, Use of latrines $(p=0.005)$, FamilyIncome $(p=0.007)$, Exclusive breastfeeding $(p=0.001)$, MP-ASI $(p=0.011)$, ImmunizationBasic $(p=0.029)$, and Childcare $(p=$ 0.018). It states that there is a relationship between Mother's Knowledge, Toilet use, FamilyIncome, ExclusiveBreastfeeding, ComplementaryFeeding, BasicImmunization, and Child care. The conclusion still needs hard efforts to increase knowledge and change behavior so that people are encouraged to make good efforts to maintain the health of toddlers, especially Stunting. Therefore, it is hoped that relevant agencies and health workers will further enhance their role in providing information and efforts related to factors regarding Stunting.

Keywords: Stunting, Mother's Knowledge, Latrine Use, Family Income, Exclusive ASI, MP-ASI, Basic Immunization, Child Caregivers.
\end{abstract}




\section{PENDAHULUAN}

Pembangunan kesehatan dalam periode tahun 2015-2019 difokuskan pada empat program prioritas yaitu penurunan angka kematian ibu dan bayi, penurunan prevalensi balita pendek (stunting), pengendalian penyakit menular dan pengendalian penyakit tidak menular ${ }^{1}$. Stunting (pendek) merupakan salah satu masalah gizi didunia. Stunting adalah salah satu masalah gizi yang berdampak buruk terhadapkualitas hidup anak dalam mencapai titik tumbuh kembang yang optimal sesuaipotensi genetiknya. Stunting dapat menghambat proses tumbuh kembang pada balita. ${ }^{2}$.

Masalah stunting (anak pendek) merupakan salah satu permasalahan gizi yang dihadapi dunia, khususnya di negara-negara miskin dan berkembang. Stunting menjadi permasalahan kesehatan karena berhubungan dengan risiko terjadinya kesakitan dan kematian, perkembangan otak suboptimal, sehingga perkembangan motorik terlambat dan terhambatnya pertumbuhan mental. Hal ini menjadi ancaman serius terhadap keberadaan anak-anak sebagai generasi penerus suatu bangsa. Anak pendek merupakan prediktor buruknya kualitas sumber daya manusia yang diterima secara luas, yang selanjutnya menurunkan kemampuan produktif suatu bangsa di masa yang akan datang ${ }^{3}$.

Secara global, sekitar 162 juta anak balita mengalami kependekan. Di tahun 2017, Indonesia menduduki peringkat ke empat dunia untuk jumlah Balita dengan kondisi stunting yaitu dengan prevelensi Stunting 36\% dengan jumlah balita 8,8 juta setelah India (39\%), Pakistan $(45 \%)$ dan Nigeria $(33 \%)^{4}$.

Dalam Strategi Nasional Pencegahan Stunting, pemerintah menetapkan 100 Kabupaten/Kota prioritas penanganan stunting tahun 2018, bertambah di tahun 2019 menjadi 160 Kabupaten/Kota prioritas dan tahun 2020-2024 akan ditetapkan semua desa di semua Kabupaten/Kota prioritas secara bertahap(TNP2K 2018). Salah satu dari 100 Kabupaten/Kota prioritas tersebut yaitu adalah Kabupaten Kerinci yang terletak di Provinsi Jambi ${ }^{5}$.

Berdasarkan data yang diperoleh dari Dinkes Provinsi Jambi di tahun 2017, Prevalensi Status Gizi Balita berdasarkan Indeks Tinggi Badan menurut Umur (TB/U) sebesar 25,2\%, terdiri dari sangat pendek dan pendek masing-masing adalah 8,8\% dan 16,4\%. Adapun prevalensi balita sangat pendek dan pendek menurut Kabupaten di Provinsi Jambi tahun 2017 adalah tertinggi di Kabupaten Kerinci sebesar 35,0\% dengan prevalensi sangat pendek 12,1\% dan pendek $22,9 \%$.

Berdasarkan data yang diperoleh dari Dinas Kesehatan Kabupaten Kerinci, hasil pemantauan status gizi adapun prevalensi balita sangat pendek dan pendek menurut Kecamatan di Kabupaten Kerinci, dari jumlah 18 Kecamatan yang termasuk 3 kategori terbanyak adalah Kecamatan Gunung Raya (66,6\%), Kecamatan Kayu Aro $(61,9 \%)$ dan Kecamatan Siulak $(41,1 \%)^{7}$.

Terdapat dua kategori penyebab stunting, yaitu penyebab langsung dan tidak langsung. Secara langsung karena masalah gizi yang disebabkan oleh rendahnya asupan gizi dan masalah kesehatan, masalah tersebut merupakan dua hal yang saling memengaruhi. Adapun pengaruh tidak langsung adalah ketersediaan makanan, pola asuh, ketersediaan air minum (bersih), sanitasi dan pelayanan kesehatan ${ }^{8}$.

Menurut Tim Nasional Percepatan Penanggulangan Kemiskinan (TNP2K), stunting disebabkan oleh berbagai faktor seperti pola pengasuhan yang kurang baik meliputi pemberian makan dalam 2 tahun pertama setelah kelahiran, masih kurangnya akses terhadap pelayanan kesehatan selama hamil dan setelah melahirkan, kurangnya akses keluarga ke makanan bergizi, serta masih terbatasnya akses air bersih dan sanitasi ${ }^{9}$.

Stunting dapat berakibat pada gangguan perkembangan kognitif, ketidak mampuan menerima pelajaran di sekolah, rendahnya produktifitas ekonomi saat dewasa, dan gangguan kehamilan. Selain hal tersebut, Stunting juga meningkatkan risiko anak terkena penyakit tidak 
menular saat dewasa. Stunting merupakan masalah yang multikausal, perlu adanya perbaikan yang bersifat komprehensif ${ }^{10}$.

Tujuan penelitian adalah mengetahui faktor risiko kejadian Stunting pada Balita di Wilayah Kecamatan Siulak Kabupaten Kerinci Tahun 2019.

\section{METODE}

Penelitian ini merupakan penelitian Kuantitatif dengan desain case control. Populasi dalam penelitian ini adalah ibu yang memiliki balita Stunting dan tidak Stunting di Wilayah Kecamatan Siulak Kabupaten Kerinci dengan jumlah sampel 88 responden, sebanyak 44 (kasus) dan 44 orang (kontrol). Sampel dipilih dengan teknik Multistage Random Sampling. Cara pengumpulan data melalui wawancara mengunakan kuesioner. Penelitian ini dilakukan pada tanggal 29 Januari - 13 Februari 2019. Data yang telah dikumpulkan dianalisis secara univariat dan bivariat dengan uji statistic uji Chi square.

\section{HASIL}

Hasil penelitian dari 88 responden diketahui bahwa sebanyak53,4\% responden memiliki pengetahuan yang rendah, 52,3\% penggunaan jamban yang kurang baik, 64,8\% pendapatan keluarga yang rendah, 55,7\% responden yang tidak ASI eksklusif, 23,9\% yang tidak MP-ASI, $39,8 \%$ yang imunisasi dasar tidak lengkap dan 54,5\% responden yang pengasuh anaknya diasuh selain ibu kandung di wilayah Kecamatan Siulak Kabupaten Kerinci Tahun 2019. Hasil tersebut terlihat pada tabel sebagai berikut :

Tabel 1. Distribusi Responden Berdasarkan Pengetahuan Ibu, Penggunaan Jamban, Pendapatan Keluarga, ASI eksklusif, MP-ASI, Imunisasi Dasar, dan Pengasuh Anak.

\begin{tabular}{|c|c|c|}
\hline Variabel & $\mathbf{n}$ & $\%$ \\
\hline \multicolumn{3}{|l|}{ Pengetahuan Ibu } \\
\hline Rendah & 47 & 53,4 \\
\hline Tinggi & 41 & 46,6 \\
\hline \multicolumn{3}{|l|}{ Penggunaan Jamban } \\
\hline Tidak memiliki jamban & 46 & 52,3 \\
\hline Memiliki Jamban & 42 & 47,7 \\
\hline \multicolumn{3}{|l|}{ Pendapatan Keluarga } \\
\hline Rendah & 57 & 64,8 \\
\hline Tinggi & 31 & 35,2 \\
\hline \multicolumn{3}{|l|}{ ASI eksklusif } \\
\hline Tidak ASI eksklusif & 49 & 55,7 \\
\hline ASI eksklusif & 39 & 44,3 \\
\hline \multicolumn{3}{|l|}{ MP-ASI } \\
\hline Tidak MP-ASI & 21 & 23,9 \\
\hline MP-ASI & 67 & 75,1 \\
\hline \multicolumn{3}{|l|}{ Imunisasi Dasar } \\
\hline Tidak Lengkap & 35 & 39,8 \\
\hline Lengkap & 53 & 60,2 \\
\hline \multicolumn{3}{|l|}{ Pengasuh Anak } \\
\hline Kurang baik & 48 & 54,5 \\
\hline Baik & 40 & 45,5 \\
\hline
\end{tabular}

Hasil analisis bivariat menunjukkan bahwa ada hubungan antara pengetahuan ibu (pvalue $=0,034)$, penggunaan jamban ( $p$-value $=0,005)$, pendapatan keluarga $(p$-value $=0,007)$, ASI eksklusif ( $p$-value $=0,001)$, MP-ASI ( $p$-value $=0,011$ ), imunisasi dasar ( $p$-value $=0,029$ ), dan pengasuh anak ( $\mathrm{p}$-value $=0,018$ ) dengan Faktor Risiko Kejadian Stunting pada Balita di 
Wilayah Kecamatan Siulak Kabupaten Kerincitahun 2019. Hasil tersebut dapat dilihat pada tabel sebagai berikut :

Tabel 2 Faktor yang Berhubungan dengan Kejadian Stunting Pada Balita

\begin{tabular}{|c|c|c|c|c|c|c|c|c|}
\hline \multirow{3}{*}{ Variabel } & \multicolumn{4}{|c|}{ Stunting Pada Balita } & \multirow{2}{*}{\multicolumn{2}{|c|}{ Total }} & \multirow{3}{*}{$\begin{array}{c}P- \\
\text { Value }\end{array}$} & \multirow{3}{*}{$\begin{array}{c}\text { Nilai } \\
\text { OR }\end{array}$} \\
\hline & \multicolumn{2}{|c|}{ Kasus } & \multicolumn{2}{|c|}{ Kontrol } & & & & \\
\hline & $\mathbf{n}$ & $\%$ & $\mathbf{n}$ & $\%$ & $\mathrm{n}$ & $\%$ & & \\
\hline Pengetahuan Ibu & & & & & & & & 2,793 \\
\hline Rendah & 29 & 61,7 & 18 & 38,3 & 47 & 100 & \multirow{2}{*}{0,032} & $(1,175-$ \\
\hline Tinggi & 15 & 36,6 & 26 & 63,4 & 41 & 100 & & $6,638)$ \\
\hline Penggunaan Jamban & & & & & & & \multirow{3}{*}{0,005} & 3,750 \\
\hline Tidak Memiliki Jamban & 30 & 65,2 & 16 & 34,8 & 46 & 100 & & $(1,551-$ \\
\hline Memiliki Jamban & 14 & 33,3 & 28 & 66,7 & 42 & 100 & & $9,068)$ \\
\hline Pendapatan Keluarga & & & & & & & \multirow{3}{*}{0,007} & 3,889 \\
\hline Rendah & 35 & 61,4 & 22 & 38,6 & 57 & 100 & & $(1,517-$ \\
\hline Tinggi & 9 & 29,0 & 22 & 71,0 & 31 & 100 & & $9,967)$ \\
\hline ASI Eksklusif & & & & & & & \multirow{4}{*}{0,001} & 5,250 \\
\hline Tidak ASI eksklusif & 33 & 67,3 & 16 & 32,7 & 49 & 100 & & $(2,096-$ \\
\hline ASI ekslusif & 11 & 28,2 & 28 & 71,8 & 39 & 100 & & 13,149 \\
\hline & & & & & & & & ) \\
\hline MP-ASI & & & & & & & & 4,457 \\
\hline Tidak MP-ASI & 16 & 76,2 & 5 & 23,8 & 21 & 100 & \multirow{3}{*}{0,011} & $(1,461-$ \\
\hline MP-ASI & 28 & 41,8 & 39 & 58,2 & 67 & 100 & & 13,598 \\
\hline Imunisasi Dasar & & & & & & & & $\frac{)}{2,921}$ \\
\hline Tidak Lengkap & 23 & 65,7 & 12 & 34,3 & 35 & 100 & \multirow[t]{2}{*}{0,029} & $(1,201-$ \\
\hline Lengkap & 21 & 39,6 & 32 & 60,4 & 53 & 100 & & $7,104)$ \\
\hline Pengasuh Anak & & & & & & & \multirow{3}{*}{0,018} & 3,095 \\
\hline Kurang Baik & 30 & 62,5 & 18 & 37,5 & 48 & 100 & & $(1,292-$ \\
\hline Baik & 14 & 35,0 & 26 & 65,0 & 40 & 100 & & $7,417)$ \\
\hline
\end{tabular}

\section{PEMBAHASAN}

Ada hubungan antara pengetahuan ibu dengan kejadian Stunting di Wilayah Kecamatan Siulak Kabupaten Kerinci Tahun 2019 dengan nilai OR (Odd Ratio) 2,793. Hasil penelitian menunjukkan bahwa responden yang memiliki pengetahuan yang rendah lebih banyak yang mengalami stunting dibandingkan dengan responden yang memiliki pengetahuan yang tinggi. Sebagian besar pengetahuan ibu yang rendah dipengaruhi oleh beberapa faktor pendidikan (tamatan SD, SMP), sikap kurang peduli dan ketidakingin tahuan ibu tentang gizi, sehingga hal ini akan berdampak pada tumbuh kembang anak balitanya yang akan mengalami gangguan pertumbuhan (Stunting).

Sejalan dengan penelitian yang dilakukan oleh Nasikhah dan Margawati (2012) ${ }^{11}$ dari hasil analisis bivariat menunjukkan pengetahuan ibu tentang gizi merupakan faktor risiko kejadian stunting yang bermakna.

Pengetahuan ibu merupakan salah satu faktor yang menentukan konsumsi makanan pada anaknya. Ibu yang mempunyai pengetahuan gizi yang baik akan mempunyai kemampuan untuk menerapkan pengetahuan gizi dalam pemilihan dan pengolahan makanan sehingga dapat diharapkan asupan makanannya lebih terjamin, baik dalam menggunakan alokasi pendapatan rumah tangga untuk memilih pangan yang baik dan mampu memperhatikan gizi yang baik. Sedangkan pengetahuan ibu yang rendah akan berdampak 
pada tumbuh kembang anak balitanya yang akan mengalami gangguan pertumbuhan (Stunting).

Ada hubungan antara penggunaan jamban dengan kejadian Stunting di Wilayah Kecamatan Siulak Kabupaten Kerinci Tahun 2019dengan nilai OR (Odd Ratio) 3,750. Hasil penelitian menunjukkan bahwa responden yang tidak mempunyai jamban lebih banyak mengalami stunting dan sebaliknya responden yang mempunyai jamban lebih banyak yang tidak mengalami stunting. Namun ada responden yang mempunyai jamban tetapi mengalami stunting hal ini dikarenakan responden dipengaruhi oleh faktor lain seperti pemberian ASI yang tidak eksklusif. Sebagian warga yang tidak memiliki jamban dipengaruhi oleh pendapatan keluarga yang rendah untuk membangun jamban, adapun pendapatan yang cukup tetapi tidak memiliki jamban dikarenakan perilaku atau kebiasaan warga yang BAB sembarangan serta menganggap BAB di aliran sungai lebih praktis. Sebagian besar responden yang tidak memiliki jamban dirumah biasanya menggunakan jamban di sungai, sawah / kebun. Sejalan dengan penelitian Maya dan Besral (2010) ${ }^{12}$ menyatakan sebanyak 34,5\% menderita stunting, dan jenis jamban yang tidak layak mempunyai risiko untuk menderita stunting 1,3 kali lebih tinggi dibandingkan dengan anak yang berasal dari keluarga dengan jenis jamban yang layak.

Dampak dalam hal ini jika dibiarkan akan mengganggu kesehatan, sanitasi yang buruk dalam halnya jamban seperti BAB sembarangan akan mencemari lingkungan, dalam hal ini lalat menjadi perantara dan pembawa bakteri penyakit dari tinja melalui makanan dan minuman. Sanitasi yang buruk dapat memicu kerusakan dinding usus akibat paparan bakteri. Hal ini dapat berisiko penyakit pada balita seperti diare, juga kecacingan sehingga mengganggu tumbuh kembang pada balita. Sehingga berakibat stunting. Untuk itu kesadaran masyarakat membangun jamban perlu disosialisasikan dan ditimdaklanjuti.

Ada faktor risiko pendapatan keluarga dengan kejadian Stunting di Wilayah Kecamatan Siulak Kabupaten Kerinci Tahun 2019dengan nilai OR (Odd Ratio) 3,889.

Hasil penelitian menunjukkan bahwa responden dengan pendapatan yang rendah lebih banyak dibandingkan dengan pendapatan yang tinggi. Dimana sebagian besar pendapatan yang rendah karena pendapatan perkapita $<500.000$ perbulan. Secara nasional BPS menyatakan pendapatan perkapita $<500.000$ perbulan dikategorikan miskin dan juga pendapatan $<1,9$ juta batas kemiskinan. Sedangkan rata-rata responden pendapatan \pm 1.500.000 termasuk rendah / dibawah batas kemiskinan. Anggota keluarga juga mempengaruhi pendapatan perkapita perbulan rendah, dimana responden dengan berpenghasilan 1.500.000 dibagi dengan jumlah anggota keluarga $>4$ orang maka pendapatan perkapita perbulan rendah. Rata-rata responden bekerja di sektor pertanian / perkebunan.

Sejalan dengan penelitian Picauly dan Toy $(2013)^{13}$, menunjukkan bahwa keluarga dengan tingkat pendapatan yang rendah memiliki peluang anaknya mengalami stunting sebesar 62,128 kali lebih besar dibandingkan dengan keluarga pendapatan yang tinggi. Tetapi pada penelitian Anindita (2012) ${ }^{14}$ bahwa tidak ada hubungan antara tingkat pendapatan dengan stunting yang menyatakan bahwa pertumbuhan bayi tidak terlalu berpengaruh dengan pendapatan keluarga.

Keluarga dengan pendapatan yang rendah akan mempengaruhi kualitas maupun kuantitas bahan makanan yang dikonsumsi keluarga. Makanan yang didapat biasanya akan kurang bervariasi dan sedikit jumlahnya terutama pada bahan pangan yang berfungsi untuk pertumbuhan pada balita sumber protein, vitamin dan mineral, sehingga meningkatkan risiko kurang gizi. Keterbatasan tersebut akan meningkatkan risiko seorang balita mengalami stunting.

Ada faktor risiko ASI Eksklusif dengan kejadian Stunting di Wilayah Kecamatan Siulak Kabupaten Kerinci Tahun 2019 dengan nilai (Odd Ratio) 5,250. 
Dari hasil penelitian menunjukkan bahwa responden yang tidak ASI eksklusif lebih banyak dibandingkan yang ASI eksklusif. Dan dalam penelitian ini variabel ASI ekslusif paling berisiko dengan nilai OR 5,250. Sebagian besar responden balita yang tidak ASI eksklusif, hal ini dipengaruhi oleh kebiasaan masyarakat memberikan makanan, air tajin, bubur, dan susu formula dan pengaruh keluarga yang tidak mendukung pemberian ASI eksklusif. Dimana desa dalam penelitian ini adalah salah satu desa migran, sebagian responden ibu balita yang pernah bekerja sebagai TKI sehingga yang meninggalkan balitanya saat bayi, dan pola asuh dari balita oleh neneknya atu pengasuh lain. Hal ini merupakan faktor penyebab bayi tidak diberikan ASI secara eksklusif. Adapun ibu lainnya yang rata-rata bekerja sebagai petani, dan bekerja ditempat lain berpengaruh terhadap pemberian ASI eksklusif.

Sejalan dengan penelitian Arifin (2012) ${ }^{15}$, hasil uji statistik diperoleh p-value $=0,0001$, disimpulkan terdapat hubungan antara pemberian ASI dengan kejadian Stunting.

ASI Eksklusif sangat berperan dalam pemenuhan nutrisi bayi. Konsumsi ASI juga meningkatkan kekebalan tubuh bayi sehingga menurunkan risiko penyakit infeksi. Dampaknya jika tidak diberikan ASI eksklusif dapat menghambat pertumbuhan dan perkembangan balita karena kurang nya pemenuhan nutrisi sehingga balita lambat tumbuh dan berisiko stunting.

Ada faktor risiko MP-ASI dengan kejadian Stunting di Wilayah Kecamatan Siulak Kabupaten Kerinci Tahun 2019dengan nilai (Odd Ratio) 4,457.

Dari hasil penelitian responden yang tidak MP-ASI lebih banyak yang mengalami stunting dibandingkan dengan yang MP-ASI. Hal ini disebabkan kurangnya pengetahuan ibu mengenai MP-ASI, dan juga faktor pola asuh karena sebagian besar balita diasuh oleh neneknya dan pengasuh lain yang mempengaruhi pemberian MP-ASI yang tidak sesuai. MPASI seharusnya diberikan pada saat usia 6 bulan. Responden yang tidak MP-ASI dikarenakan responden pemberian MP-ASI terlalu dini dan adapundiberikan terlambat $>6$ bulan.

Dampak dari MP-ASI apabila penundaan waktu pemberian MP-ASI sesudah 6 bulan menyebabkan gangguan pertumbuhan dan perkembangan, seperti badan bayi tidak bertambah dan pertumbuhan terhambat (pendek). Dan MP-ASI yang diberikan secara dini sebelum 6 bulan akan berpengaruh pada pencernaan bayi.

Sejalan dengan penelitian yang dilakukan Wiyogowati $(2012)^{16}$ bahwa kejadian stunting pada anak balita dipengaruhi oleh variabel pemberian MP-ASI.

Makananan Pendamping ASI adalah makanan atau minuman yang mengandung zat gizi,diberikan pada bayi atau anak usia 6-24 bulan guna memenuhi kebutuhan gizi selain dari ASI (Depkes, 2006) ${ }^{17}$. Tujuan pemberian makanan pendamping ASI adalah untuk menambah energy dan zat —zat yang diperlukan bayi karena ASI tidak dapat memenuhi kebutuhan bayi secara terus menerus. Pemberian MP-ASI yang tepat merupakan faktor proktektif terhadap terhadap kejadian stunting pada balita.

Ada faktor risiko imunisasi dasar dengan kejadian Stunting di Wilayah Kecamatan Siulak Kabupaten Kerinci Tahun 2019dengan nilaidengan nilai OR (Odd Ratio) 2,921.

Penelitian ini menunjukkan bahwa responden yang imunisasi nya tidak lengkap lebih banyak mengalami stunting dibandingkan dengan responden yang imunisasi nya lengkap mengalami stunting. Balita yang imunisasi dasarnya tidak lengkap dipengaruhi oleh faktor ibu atau keluarga, dimana ibu atau keluarga yang sibuk bekerja hingga lupa untuk membawa anak imunisasi dan juga ada yang terkadang malas dan lalai. Kurangnya pengetahuan ibu dalam pentingnya pemberian imunisasi pada anak. sebagian besar balita yang imunisasinya belum lengkap yaitu campak (usia 9 bulan). Dimana pemberian imunisasi harus lengkap untuk kekebalan tubuh anak maupun agar terhindar dari penyakit. 
Hasil penelitian lain oleh Picauly, dkk $(2013)^{13}$ menunjukkan bahwa anak yang memiliki riwayat imunisasi tidak lengkap memiliki peluang mengalami stunting lebih besar daripada yang memiliki riwayat imunisasi lengkap.

Imunisasi adalah suatu upaya untuk menimbulkan atau meningkatkan kekebalan seseorang secara aktif terhadap suatu penyakit, sehingga bila suatu saat terpajan dengan penyakit tersebut tidak akan sakit atau hanya mengalami sakit ringan (permenkes, 2013) ${ }^{18}$.

Imunisasi sangat penting dan bermanfaat untuk kekebalan tubuh seorang anak sehingga tidak mudah terserang penyakit. Jika dibiarkan tidak imunisasi akan mudah anak terkena penyakit dan menghambat pertumbuhan nya sehingga balita menjadi pendek (stunting). Untuk itu sangat penting imunisasi dasar pada anak.

Ada faktor risiko pengasuh anak dengan kejadian Stunting di Wilayah Kecamatan Siulak Kabupaten Kerinci Tahun 2019dengan nilai OR (Odd Ratio) 3,095.

Hasil penelitian menunjukkan bahwa sebagian responden balita yang sehari-harinya diasuh oleh selain ibu kandung, diasuh oleh neneknya maupun pengasuh lainnya. Ini dipengaruhi oleh faktor ibu balita yang bekerja. Pengasuh balita yang sehari-hari neneknya akan berpengaruh pada cara pemberian makan pada balita. Seperti contohnya nenek yang mengasuh bayi sebelum bayi 6 bulan akan memberikan makanan atau minuman selain asi jika bayi nya menangis karena iba terhadap bayinya khawatir bayi itu lapar, adapun responden yang diasuh nenek nya memberikan air tajin pada balita sebelum 6 bulan karena kebiasaan. Maka itu akan bepengaruh terhadap perkembangan dan pemenuhan nutrisi balita yang seharusnya. Berbeda dengan jika diasuh oleh ibu kandung sehari-hari pastinya bayi tersebut akan selalu diberikan gizi yang baik seperti selalu diberikan asi. Untuk itu pentingnya pola asuh pada balita. Sebaiknya untuk pengasuh anak selain ibu nya diberi pengetahuan atau diajarkan mengasuh anak dengan baik.

Penelitian sejenis Renyoet $(2012)^{19}$ bahwa ada hubungan yang permakna antara pola asuh dengan status gizi balita dimana pengasuh anak dalam pola asuh makan yang kurang berdampak pada kejadian stunting. Penelitian lainnya Yulita, bahwa ada hubungan signifikan antara pengasuh anak dengan kejadian stunting. (Yulita, 2014) ${ }^{20}$.

Pola asuh yang baik pada anak dapat dilihat pada praktek pemberian makanan atau pola asuh makan yang baik yang berdampak terhadap tumbuh kembang dan kecerdasan anak yang di tentukan sejak bayi maupun sejak dalam kandungan. Dalam memberikan pola asuh juga perlu diimbangi dengan kondisi orang tua yang seimbang, pengausahan oleh orang tua yang tidak dalam tekanan seperti stress dan penyakit tidak menular lainnya misalnya Hipertensi dan lain-lain $^{21}$. Selain itu praktek perawatan kesehatan dan stimulasi pada anak juga berpengaruh terhadap perkembangan anak.

\section{KESIMPULAN}

1. Ada hubungan antara pengetahuan ibu dengan kejadian Stunting. Dengan nilai P-Value $0,032<0,05$ dan OR (Odd Ratio) 2,793 yang berarti memiliki risiko 2,7 kali untuk yang berpengetahuan rendah mengalami stunting.

2. Ada hubungan antara penggunaan jamban dengan kejadian Stunting. Dengan nilai P-Value $0,005<0,05$ dan OR (Odd Ratio) 3,750 yang berarti memiliki risiko 3,7 kali untuk yang tidak memiliki jamban mengalami stunting.

3. Ada hubungan antara pendapatan keluarga dengan kejadian Stunting. Dengan nilai PValue 0,007 < 0,05 dan OR (Odd Ratio) 3,889 yang berarti memiliki risiko 3,8 kali untuk yang pendapatan rendah mengalami stunting.

4. Ada hubungan antara ASI Eksklusif dengan kejadian Stunting. Dengan nilai P-Value 0,001 $<0,05$ dan OR (Odd Ratio) 5,250 yang berarti memiliki risiko 5,2 kali untuk yang tidak ASI eksklusif mengalami stunting. 
5. Ada hubungan antara MP-ASI dengan kejadian Stunting. Dengan nilai P-Value 0,011 < 0,05 dan OR (Odd Ratio) 4,457 yang berarti memiliki risiko 4,4 kali untuk yang tidak MPASI mengalami stunting.

6. Ada hubungan antara imunisasi dasar dengan kejadian Stunting. Dengan nilai P-Value $0,029<0,05$ dan OR (Odd Ratio) 2,921 yang berarti memiliki risiko 2,9 kali untuk yang imunisasi dasar tidak lengkap mengalami stunting.

7. Ada hubungan antara pengasuh anak dengan kejadian Stunting. Dengan nilai P-Value 0,018 < 0,05 dan OR (Odd Ratio) 3,095 yang berarti memiliki risiko 3,0 kali untuk yang pengasuh nya kurang baik mengalami stunting.

\section{SARAN}

Diharapkan pemerintah atau dinas kesehatan dapat memperluas penguatan dan perluasan cakupan program gizi spesifik (IMD, ASI eksklusif, MP-ASI, imunisasi) dan kegiatan sensitif (ekonomi, sanitasi, infrastruktur akses pelayanan, pendidikan). Kepada pihak puskesmas, petugas kesehatan, maupun kader setempat agar lebih aktif melakukan kunjungan dan penyuluhan mengenai pentingnya pola asuh terhadap balita, MP-ASI, ASI eksklusif, sweeping imunisasi yang dilakukan petugas kesehatan serta mengingatkan pentingnya imunisasi, dan lebih meningkatkan kebersihan diri dan lingkungan masyarakat.

\section{DAFTAR PUSTAKA}

1. Kementerian (PPN) Perencanaan Pembangunan Nasional / Badan Perencanaan Pembangunan Nasional. 2014. Buku I Rencana Pembangunan Jangka Menengah Nasional 2015-2019.

2. Kemenkes RI, 2015. PedomanGiziSeimbang. Jakarta: Departemen Kesehatan.

3. Unicef Indonesia, 2013. Ringkasan Kajian Gizi Ibu dan Anak, Oktober 2012. www.unicef.org

4. Unicef, WHO, World Bank (2017). Levels and trends in child malnutrition. www.who.int/nutgrowthdb/jmeunicefwhowb.pdf

5. Tim Nasional Percepatan Penanggulangan Kemiskinan (TNP2K). 100 Kabupaten/Kota prioritas untuk intervensi anak kerdil (stunting). Jakarta : 2018.

6. DinkesProvinsi Jambi. Laporan Penilaian Status Gizi (PSG) Provinsi Jambi Tahun 2017. Jambi : Pemerintah Provinsi Jambi ; tahun 2017.

7. Dinkes Kabupaten Kerinci .Laporan Penilaian Status Gizi (PSG) Kabupaten Kerinci Tahun 2017. Jambi : Pemerintah Kabupaten Kerinci ; tahun 2017.

8. Kemenkes RI (2013). Riset Kesehatan Dasar (RISKESDAS) 2013. Jakarta : Badan Penelitian dan Pengembangan Kesehatan Kementerian Kesehatan RI.

9. Tim Nasional Percepatan Penanggulangan Kemiskinan (TNP2K). Buku Saku Ringkasan Stunting. Jakarta : 2017.

10. Dewey, K.G.\& Begum, K (2011) Longterm qonsequences of stunting in early life. Matern Child Nutr, 7(s3) 5-18.

11. Nasikhah, R.,\&Margawati, A. (2012) Faktorkejadian stunting padabalitausia 24-36 bulan di Kecamatan Semarang Timur. Journal of Nutrition College, 1(1): 715-730

12. Adiyanti, M., danBesral. 2014. PolaAsuhGizi, SanitasiLingkungan, danPemanfaatanPosyandudengankejadian Stunting padaBaduta di Indonesia (Analisis Data RiskesdasTahun 2010). Universitas Indonesia.

13. Picauly I, Toy SM. 2013. AnalisisDeterminan Dan Pengaruh Stunting TerhadapPrestasiBelajarAnakSekolah Di Kupang Dan Sumba Timur, NTT. JurnalGizidanPangan. 8 (1) : 55 - 62. 
14. Anindita P. 2012. Hubungan Tingkat PendidikanIbu, PendapatanKeluarga, Kecukupan Protein Dan Zinc DenganStunting PadaBalitaUsia $6-35$ Bulan Di KecamatanTembalang Kota Semarang. JurnalKesehatanMasyarakat. 1(2) : 617 - 626.

15. Arifin, D.Z, S.Y, Irdasari. dan H. Sukandar . 2012. Analisis Sebaran dan Faktor Risiko Stunting pada Balita di Kabupaten Purwakarta 2012. Epidemiologi Komunitas FKUP.

16. Wiyogowati, Citaningrum. (2012). Kejadian Stunting pada Anak Umur dibawah Lima Tahun (0-59 Bulan) di Provinsi Papua Barat Tahun 2010 (Analisa Data Riskesdas 2010). Fakultas Kesehatan Masyarakat Universitas Indonesia.

17. Departemen Kesehatan RI., 2006. Pedoman Umum Pemberian Makanan Pendamping Air Susu Ibu (MP-ASI) Lokal. Jakarta : Departemen Kesehatan RI pp. 2

18. Permenkes No.42 tahun 2013. Jakarta: Kemenkes RI; 2013.

19. Renyoet BS, Hadju V, Rochimiwati. 2012. HubunganPolaAsuhDenganKejadian Stunting AnakUsia 6-23 Bulan Di Wilayah Pesisir Kecamatan Tallo Kota Makasar Tahun 2012. Http://repository.unhas.ac.id.

20.Yulita, R. 2014. Hubungan Pola Asuh Orang Tua Terhadap Perkembangan Anak Balita Di Posyandu Sakura CiputatTimur. Jakarta : UIN Syarif Hidayatullah.

21. Kurniawan I, Sulaiman, Hubungan Olahraga, Stress dan Pola Makan dengan Tingkat Hipertensi di Posyandu Lansia di Kelurahan Sudirejo I Kecamatan Medan Kota. Journal of Health Science and Physiotherap 1 (1), (10-17) 